\title{
Librarians Work-Related Learning and Self- Development: Trends in Estonian University Libraries
}

\author{
Kate-Riin Kont ${ }^{*}$, Signe Jantson \\ Akadeemia tee 1, Tallinn 12618, Estonia \\ *Corresponding author: kate-riin.kont@ttu.ee
}

Received January 30, 2015; Revised February 27, 2015; Accepted March 09, 2015

\begin{abstract}
Purpose The aim of the current paper is to clarify if the staff of Estonian university libraries has enough opportunities and willingness for continuing education and to develop their skills and competencies related with their everyday work in formal as well as in informal form; whether they have sufficient skills for their current job and what kind of knowledge/skills do librarians miss the most and finally, whether their current income will allow them to continue their education. Methodology The data used in this paper is based on reviewing of relevant literature to provide an overview of the concept of learning and development, and also on the results of the original survey, created by the paper's authors, held in Estonian university libraries governed by public law in Estonia. The analysis of the results are interpreted on the basis of the literature and authors' opinions, based on long-term working experience in Estonian academic libraries. Findings Although the personnel of university libraries are highly motivated to train themselves, and some are even willing to do it at their own expense, most librarians are relatively pessimistic about their opportunities to develop themselves with their current salary. The increasing salary would be the biggest motivator for continuing education and self-development. There are a number of employees in university libraries who would be willing to participate in professional conferences and seminars. Unfortunately, most of the them are not ready to deliver a presentation. Originality/value The majority of the literature in library science has focused - and rightfully so - on the user: what do users and patrons want and/or need, how do they use it, how can librarians best provide it to them, do the users feel themselves comfortable in library building etc., etc. To the best of the authors' knowledge, no research has been carried out in recent years, in the Estonian university library context to determine continuing education and development. Practical implications Based on the current study it can be said that the biggest challenge for managements of the university libraries in Estonia is to find the opportunities for financial and/or time support which could influence all kind of the development and learning activities of employees.
\end{abstract}

Keywords: university librarians, formal education, informal education, continuing professional education, selfdevelopment, institutional support

Cite This Article: Kate-Riin Kont, and Signe Jantson, "Librarians Work-Related Learning and SelfDevelopment: Trends in Estonian University Libraries.” American Journal of Educational Research, vol. 3, no. 3 (2015): 366-376. doi: 10.12691/education-3-3-16.

\section{Introduction}

Learning has become more and more important both in a personal and organizational context. The nature of work is turned to be more complex than ever before and due to this more people with ability to settle in and to develop are needed in an organization. (Brooks, 48-51). As knowledge has become the key factor for achieving efficient service and high productivity, organizations need people with high levels of knowledge, skills and abilities, which eventually lead to desirable organizational success. Beyond doubt, organizations are interested in continuing learning of the staff because of the improving skills and flexibility of the employee (Brooks, 2008, pp. 48-51). M. Armstrong in his "Handbook of human resource management practice" (2012) says that "Everyone in the organization should be encouraged and given the opportunity to learn - to develop their skills and knowledge to the maximum level of their capacity. Therefore, the organization needs to invest in learning, continuing education and development by providing appropriate learning opportunities and facilities" (Armstrong, 2012, p. 276), or by providing financial and/or time support (for example, paid leave) (Havener \& Stolt 1994).

There is a great deal of support for the notion that librarians have a deep commitment to professional development and continuing education. Previous studies have approached the topic of librarian learning and development activities from a variety of angles and most of them have looked for answers to a series of questions. Some studies have focused on specific types of libraries, with academic librarians being most heavily studied (Neal, 1980; Hegg, 1985; Havener \& Stolt, 1995; Flately \& Weber, 2004; Pan \& Hovde, 2010). Some studies have analyzed among other things the continuing education needs of a specific group of librarians, for example the 
relationship between age and/or length of service as a professional librarian and participation in learning and development activities (Stone, 1970; Hegg, 1985; Long \& Applegate, 2008). Some research to date has explored the motivations of librarians for participation in continuing education (Stone, 1970; Neal, 1980; Smith \& Burgin, 1991; Chan \& Auster, 2003). Recent studies have also shown that there is a great desire for technology-related continuing education (Hider, 2006; Long \& Applegate, 2008; Leysen \& Boydston, 2009). Many factors affect the level and kinds of learning and development activities librarians can undertake, and institutional support, along with release time and financial assistance, has been mentioned to be one of the most important (Shelley \& Nedria, 1990, Havener \& Stolt, 1995; Chan \& Auster, 2003; Long \& Applegate, 2008; Pan \& Hovde, 2010).

The existing literature, however, focuses more on training than on learning, more on formal education than on informal education, on what librarians actually do to cope with the demands of their changed world of work (Varlejs, 1999, p. 173).

Organizational restructuring, transition from printed scientific information to digital information and new technological challenges have resulted in changing roles for librarians. Libraries are more and more becoming about supporting study and research, not storing books. Librarians need to become effective marketeers, they must think from the user's point of view, create services they need, and be effective in promoting them. Communications skills are key for librarians - they have to communicate all the time - written and verbal. They have to be able to speak in public - there are talks and workshops and meeting which form the bulk of interaction with the departments. Librarians have to communicate new ideas successfully and get support for them. The knowledge and skills that librarians have acquired through formal education and on-the-job experience may no longer be relevant for jobs that have been redesigned for advanced knowledge and skills (Auster \& Chan, 2003, pp. 57-58; Anyangwe, 2012).

The area of learning, continuing education and professional development is quite unexplored field in Estonian university libraries. Very few continuing education and training related surveys involving librarians have been carried out in Estonia, but specially in the area of public libraries (i.e. Samp, 2002).

In January 2012, a survey, using an online questionnaire method, was performed in Estonian university libraries governed by public law. These libraries were chosen because they are funded on a similar basis, they perform the same functions and their main aim is to support high quality education and to increase the state's potential for ongoing scientific discovery and development. University libraries are considered to be "legal persons in public law" (i.e., a corporate entity with the standing of an individual) and are one of the autonomous, independently functioning scientific, educational, and cultural institutions that act on the basis of science and developmental activities stipulated in the statutes of their parent universities and other legislation. Because of the high demands provided for the university libraries, also the demands for university library employees are very high. Connected with the fact that the initial questionnaire included 71 questions, together with questions about the respondents and some specifying questions, the authors of the survey decided to analyze only the B-part of the questionnaire for the purpose of the current paper. The aim of the current article is to ascertain the following indicators of librarians:

- in which areas university librarians feel the need to update knowledge and/or improve skills in their current position;

- relationship between the willingness toward continuing education and development and continuing education activities experience;

- formal and informal activities for librarians' continuing education and self-development;

- relationships between the participation of librarians in learning and development activities and individual characteristics (e.g., length of service as a professional librarian, motivation, barriers to participation (like lack of knowledge about the learning activities, lack of finances)).

The first part of the article provides an overview about the constituents of learning, education and development as well as about the studies on the continuing education, learning and professional development in the library and information science (LIS) literature. The second part describes the research methodology and characterization of the respondents. The third part presents the analysis of the results of the study.

The analysis of the results are interpreted on the basis of the relevant literature and authors' opinions, based on long-term working experience in Estonian academic libraries.

\section{Literature Review}

\subsection{The Constituents of Learning and Development}

Michael Armstrong says in his Handbook of Human Resource Management that: "Learning and development is defined as the process of ensuring that the organization has the knowledgeable, skilled and engaged workforce it needs. It involves facilitating the acquisition of knowledge and skills through experience by individuals and teams, learning events and programmes provided by the organization, guidance and coaching provided by line managers and others, and self-directed learning activities carried out by individuals” (Armstrong, 2012, p. 274).

J. G. Neal refers Elisabeth W. Stone's PhD dissertation from 1969. Stone views continuing education in librarianship as "all activities and efforts by librarians to upgrade their knowledge, abilities, competencies, and understanding in their field of work or specializations so that they can become more effective professionals and be able to handle responsibilities of greater scope and accountability.” (Neal, 1980, p. 129).

Some authors are in the opinion that learning should be distinguished from training/education. According to Buckley \& Caple (2007, p. 8), learning is the process by which a person constructs new knowledge, skills and capabilities, whereas training usually involves the acquisition of behaviours, facts, ideas, etc. that are more easily defined in a specific job context. 
Learning and development activities can be characterized as formal, informal and on-the-job types of activities. Formal education involves careful planning, has set outcomes or learning objectives and the person is conscious of their learning experience (Steptoe-Warren, 2013, p. 129). Formal activities include courses and workshops offered in-house, by educational institutions, or by professional associations (Livingstone, 1999; Chan \& Auster 2004). Formal activities are organized, structured programs that explicitly aim to foster understanding, knowledge and skills. Workshops offered by educational institutions are an example of formal activities (Livingstone, 1999; Auster \& Chan, 2004).

Informal education occurs spontaneously and in many different places such as at work, at home and through interactions with other people. This takes place independently from trainer-led programmes, outside educational establishments and is not assessed (SteptoeWarren, 2013, p. 130). Informal activities include attending conferences, discussions with colleagues, participating in e-mail discussion lists, reading the professional literature and pursuing self-directed projects. Informal activities also involve the pursuit of understanding, knowledge and skills, but outside the curricula of educational or academic institutions and professional associations. Informal learning occurs opportunistically and without strict timetables (Livingstone, 1999; Auster \& Chan, 2004). Conference attendance can considered an informal activity because of the myriad opportunities to network and interact socially and professionally with a wide range of peers and colleagues.

On-the-job education involves the acquisition of skills while working on the job. It may involve following written and verbal instructions as well as observing others and then attempting the task. This form of education usually involves a supervisor or an experienced employee passing on their knowledge and skills to the trainee (Steptoe-Warren, 2013, p. 129). Although on-the-job education is mentioned here, the current article is focused to the formal and informal types of activities.

\subsection{Motivation to Participate in Learning and Development Activities}

People will learn more effectively if they are motivated to learn. Reynolds and Mason (Reynolds \& Mason, 2002, p. 34) commented: "The disposition and commitment of the learner - their motivation to learn - is one of the most critical factors affecting learning effectiveness. Under the right conditions, a strong disposition to learn, enchased by solid experience and a positive attitude, can lead to exceptional performance”. M. Armstrong highlihts goal theory and states that "motivation is higher when individuals aim to achieve specific goals, when these goals are accepted and, although difficult, are achievable, and when there is feedback on performance. Learning goals may be set for individuals (but as effective motivators they must be acceptable) or individuals may set their own goals (self-directed learning)” (Armstrong, 2012, p. 280).

By W. Fisher and J. M. Matarazzo (1993) “The importance of continuing education is a necessary component of professional life. Given the brevity of the explosive nature of the technological and international changes taking place in libraries, continuing education is without doubt necessary. Continuing education is important in every profession and it is absolutely essential in a professional environment where rapid change alters the scope, knowledge base, and methodologies of that profession (Fisher \& Matarazzo, 1993, pp. 290-291).

By Long \& Applegate (2008) "Continuing education, learning and professional development in librarianship is a ubiquitous topic but it can be characterized as fragmentary and contradictory. As professionals whose job it is to assist users with their knowledge needs, librarians recognize the necessity of remaining lifelong learners in order to keep pace with the ever-expanding amount of available information. The area of professional practice experiencing the most rapid change over the last decade and a half has been information technology, especially the Web and its many applications” (Long \& Applegate, 2008, p. 172). Librarians must not only know how to use these emerging technologies in their jobs, they also must be able to instruct the library users how to operate these systems.

As the library's most valuable asset, the staff must be encouraged to upgrade their educational and professional qualifications. Efforts must also be made to sharpen their skills regularly with the attendance of academic conferences, seminars and workshops within and outside the library and information science (LIS) area. The more the library staff benefit from continuing education and training, the more they would become skilful, confident and above all interested in the library work itself. Their future prospects for promotion and advancement would be enhanced too (Senyah, 2003, pp. 85, 88). Changing technology is typically cited as a reason for greater investment in staff development (Woodsworth, 1998, p. 62). No matter how automated an organization or a library may be, high productivity depends on the level of motivation and the effectiveness of the workforce.

Supporting staff training and education is an indispensable strategy for motivating workers. This will give the librarian or information professional opportunities for self-improvement and development to meet the challenges and requirements of new equipment and new techniques of performing a task (Tella et al., 2007, p. 4). The literature on competence suggests that motivation to update is the most salient determinant of participation in learning and development activities. In Stone study (1970) it was found that the greatest motivations for engaging in professional development activities were concerned with the nature of the content of the development opportunity or its relation to the work process (Stone, 1970, p. 67). The studies that have examined the link between perceived benefits of training and participation have found that intrinsic benefits of training (e.g., personal satisfaction) and extrinsic benefits of training (e.g., better pay) were significant predictors of participation (Chan \& Auster, 2004, p. 268).

\subsection{Academic Librarians and Participation in Learning and Development Activities}

Academic librarians, of course, are required to obtain the highest possible level of achievement in their field. This is certainly the case with librarianship in general and with academic librarianship in particular. 
With the increasing variety of formats in which information is available, the expanding dependence on technology, the changing nature and internationalization of university library clientele, and the demand for library managers with the skills to cope with the growing size and complexities of libraries and library networks, the profession has begun to assume a greater responsibility for the provision of continuing education possibilities for its members (Neal, 1980, p. 128). Both formal as well as informal continuing education and development activities are very important for academic librarians.

The purpose of participating in professional development of academic librarians is twofold. On the one hand, it's a necessary part of working in the academic environment. As academic professionals university librarians are often expected to participate in the same process as teaching faculty do. This may include lecture in information literacy, teaching information seeking in some specific field, but also promotion through the academic ranks and tenure. On the other hand, professional development has also been shown as being instrumental in the retention of librarians especially of underrepresented librarians (Flately \& Weber, 2004, p. 492).

In library and information science curricula, it is possible to pass applied higher education studies, bachelor's studies, master's studies, and doctoral studies. By Flately \& Weber (2004, p. 488), "In the fast paced world of academic librarianship, it seems almost impossible to keep up with the change. Yet this has become both a mandate and an expectation - that the information professional have expert knowledge of new information products, procedures, and services”.

In addition to the demands to have expert knowledge of new information products, procedures and services, the new academic librarian is expected to develop competencies as their careers grow, e.g., change management, leadership development, project management, problem solving, decision making, and time management. Also, the university library professional is expected to become involved with professional development activities. It involves participation in professional organizations, making a presentation in conferences, publishing articles and other professional development activities outside working hours. This is especially aimed at young specialists, who have just come to work in the library and who would otherwise have a hard time finding appropriate skill implementation and development opportunities.

Therefore, it can be said that in the process of the continuing education, the informal activities are just as important or even more important for university librarians as the formal activities. The study about the continuing education attitudes and experience of academic librarians, conducted among the librarians of the City University of New York, clearly demonstrated that librarians favor the interaction (meeting with other librarians at conferences and association activities) and self-study modes over formal course work (Neal, 1980, p. 130).

\subsection{Length of Professional Library Experience and Participation in Learning and Development Activities}

Based on human capital theory, age is expected to affect an individual's motivation to update and an organization's willingness to train the individual. When the level of involvment in continuing education was examined by age in study, concluded among academic librarians in United States 1982, the most heavily involved were the youngest (47\%). Only $14 \%$ over the age of 60 participated in continuing education activities. The longer librarians were served in their library career in total, the less likely they were to have engaged in continuing education. Conversely, those newest to the profession reported the most participation (Hegg, 1985, p. 49). Older workers (45 years and older) are considered at risk for obsolescence, yet older workers are less likely to receive employer-sponsored training. Older workers are seen as resistant to change, less interested in challenging jobs, and as a poor investment for training. Older individuals who are nearing retirement might be expected to be less willing to participate in updating (Chan \& Auster, 2004, p. 268).

On the other hand, empirical research has shown that, for all classes of workers, including librarians, age did not always act as a deterrent to participation in updating activities. Furthermore, longer tenure in an organization was related to greater participation in updating activities. In contrast, longer tenure is related to reduced participation in informal training (Chan \& Auster, 2004, p. 268). Results of the study among the librarians of the City University of New York showed the positive relationship between continuing education activities and experiences. It is not clear whether affirmation breeds involvement, or vice versa. Nevertheless, those librarians who recognized the need for such participation and viewed it positively also tended to be more actively involved. The middle-age (age group of 40 to 49 years) and mid-career librarian (1120 years since library degree) maintained a more positive attitude toward continuing education activities and was more extensively involved than other groups. Clearly, years of experience and time since completion of library degree are important factors in producing recognition of the need to update knowledge and improve skills (Neal, 1980, pp. 130-132).

\subsection{Institutional Support and Participation in Learning and Development Activities}

Managerial support is a significant factor in the participation of employees in training and development activities. Institutional support is the perception that managers and supervisors in the organization actively support employees in their updating efforts. Managers and supervisors must act as gatekeepers to training and development opportunities (Chan \& Auster, 2004, p. 270).

Administrative support is an obvious and essential element in the professional development process (Pan \& Hovde, 2010). Most articles on institutional support for professional development seem to be written with an underlying assumption that support does, indeed, have a positive influence upon professional development. However, practical concerns, particularly the inability to budget sufficient funds and time, frequently make involvement difficult (Neal, 1980, p. 132).

Academic libraries in United States provide great institutional support for professional development activities in the belief that such support fosters the 
continuing professional growth of their staff members (Havener \& Stolt, 1994, p. 25). Although there are many potential types of institutional support, like secretarial support, computer support, positive performance appraisals, and mentoring programs, then time and money are the most commonly mentioned means of institutional support (Havener \& Stolt, 1994, p. 27). Institutional support is strongly correlated with librarians' activity level concerning the continuing education and development, while lack of time was indicated as the primary deterrent, followed by prohibitive costs. Stone (1969) concluded that the major deterrents were those factors "associated with extrinsic conditions," while Martin (1974) found that insufficient time and money were the major frustrations (Neal, 1980, p. 131). Also, the survey conducted among 185 librarians in Oklahoma, USA, in 1991 (Havener \& Stolt, 1994) showed that the time (paid leave) and the financial support that is granted by an employer or a library for the self-development activities of an employee, is crucial for the employee's preparedness for in-service trainings. The results showed that the library's support influences the most the participation in professional seminars, conferences, workshops, and meetings - those librarians who received support, participated in these events at a level of almost one hundred per cent. The library's support was also a very important motivational factor for librarians' formal education and for those librarians who were interested in research. In 2002, Anne Samp studied the needs and opportunities of in-service training of information specialists and librarians in Estonia. The primary reasons for not taking any postgraduate courses are lack of finances and intensive working hours e.g. lack of time (Samp, 2002).

Professional librarians need to continue their education throughout their career as contexts change. Many of the principles learnt at library school may still be relevant thirty years down the line, but some of them would likely require revision, or at least reinterpretation. Nevertheless, librarians cannot expect the employer to cover all the education as opposed to the training (Hider, 2006, p. 37). Both the individual and the institution share responsibility for continuing professional development (Havener \& Stolt, 1994, p. 35).

\section{Research Methodology and Data Collection}

This study was conducted in a quantitative manner. A quantitative approach was used to gather data by distribution of questionnaire to the sample. Also several open questions were used to gather the information that would justify the answers to certain questions. For compiling the questionnaire, the authors analyzed several previous studies and also qestionnaire appendixis of these studies. (Kuvaas, 2006; Gabris \& Mitchell, 1988; Harris, 1988; Schneider et al., 2003; Snape et al., 1998; Murray, 1999; Leckie \& Brett, 1997). The questionnaire was divided into four sections: A) Job satisfaction: general issues; B) Learning and individual development; C) Division of labor and coordination; D) Performance measurement and appraisal. Connected with the fact that the initial questionnaire included 71 questions, together with questions about the respondents and some specifying questions, the authors of the survey decided to analyze only the questions, concerning the career for the purpose of the current paper. To identify librarians attitudes, fivepoint and three-point interval scale (so called Likert-scale), discrete numerical five-point scale and multioption scale were used in this questionnaire. An online survey was used to gather data once at the same point of time for each participating library. The samples were the librarians working in the selected university libraries.

The population of the current study is all professional staff and qualified specialist staff (see also ISO 2789:2006. Information and documentation. International library statistics, Estonian language version in 2007, clause 3.6.3 - 3.6.6). The questionnaires were applied to 195 library staff working in selected university libraries. 111 completed questionnaires were received back. The rate of receiving back was 57\%. Data obtained from the completed questionnaires was analyzed using simple percentages, tables, bar charts and pie-charts.

8 men and 103 women responded to the questionnaire. That kind of generic divide characterizes Estonian library staff as a whole - first of all due to the low salary, librarianship has developed into the field of work predominantly for women.

The major part of respondents receive monthly income less than $500 €$ (52 respondents, that is, $47 \%$ of respondents) or their income remains between $500 €$ and $700 €$ (47 respondents, 42\%). 10 respondents (9\%) receive monthly from $700 €$ to $900 €$ and only 2 respondents receive monthly income over $900 €$.

The most active respondents belonged to the age groups of 41 to 50 years (29 persons, 26\%) and 51 to 60 years (26 persons, 24\%), followed by the respondents from the age groups of 31 to 40 years (20 persons, 18\%), 61 to 70 years (19 persons, $17 \%$ ), and 21 to 30 years (16 persons, 14\%). Only one respondent fell into the age group of 71 to 81 years, which makes up 1\% of the respondents.

The length of professional employment varied a lot. $16 \%$ of respondents had been professionally employed less than 5 years, $6 \%$ of respondents - for 5 to 9 years, $32 \%$ of respondents - for 10 to 19 years, $23 \%$ of respondents - for 20 to 29 years, $18 \%$ of respondents - for 30 to 39 years, and $5 \%$ of the respondents - for 40 to 49 years.

By professional status, $73 \%$ of respondents were specialists, $12 \%$ middle managers and $15 \%$ chief specialists.

\section{Results}

University librarians, of course, are required to obtain the highest possible level of achievement in their field. It is possible to pass applied higher education studies, bachelor's studies, master's studies, and doctoral studies. $25 \%$ of the respondents have secondary or vocational secondary education, $4 \%$ of the them reported to have vocational higher education in the field, $49 \%$ have acquired academic degree or professional higher education in the field and $10 \%$ in other area. By Flately \& Weber (2004, p. 490) one important factor to consider is the need for additional advanced degrees. Even though it is not a requirement of employment, many academic libraries expect librarians to complete an additional advanced 
degree. This could include a second master's degree or doctoral degree. It's important to consider a degree that complements the work that employee is doing. $10 \%$ of the respondents reported to have a M.A. degree in library and information science and $2 \%$ have doctoral degree.

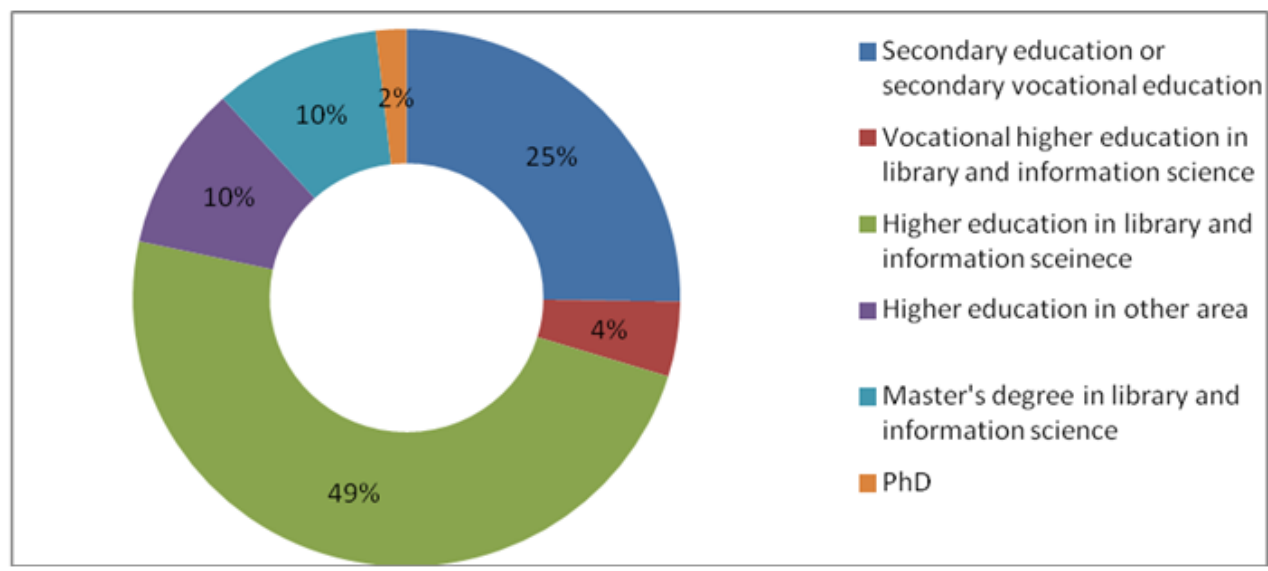

Figure 1. Distribution of the survey respondents on the basis of education

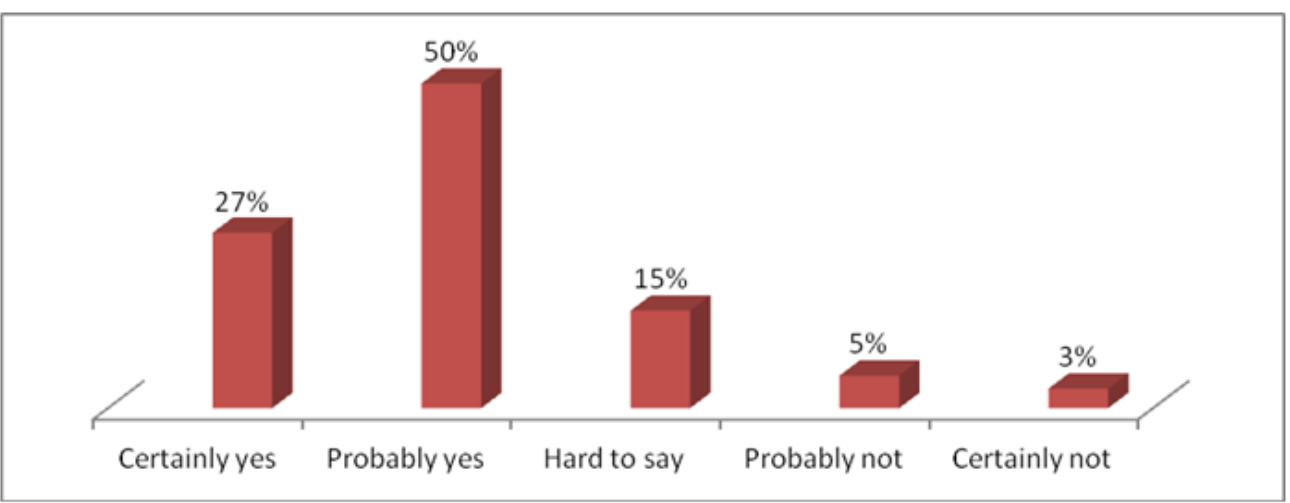

Figure 2. Librarians' opinions about their sufficient knowledge and skills for their current position

In Figure 2, we can see that the surveyed librarians and specialists have a high self-esteem: $77 \%$ consider that they have sufficient knowledge and skills for their current position, only $15 \%$ are hesitant and $8 \%$ believe that they lack sufficient knowledge and skills.

As shown in Figure 3, the highest level of respondents who value their knowledge and skills as sufficient we can find from the groups of 40 to 49 years and 20 to 29 years of service in the field of librarianship (respectively altogether $100 \%$ and $88 \%$ have answered either "Certainly yes" or "Probably yes"). Also, the respondents with the less than 5 years library experience value their knowledge and skills as sufficient. For a new librarian, formal classroom instruction covers primarily generalized knowledge about the library work as a whole, fundamental concepts and theories of library systems and operations. New hires, fresh from school with a recent curriculum, have also a relatively high self-esteem. After a few years of library work experience, the employee seems to realize that the knowledge and skills she/he got from occupational training are not sufficient. Therefore, it is not very surprising that more sceptic ones about their sufficient knowledge and skills we can find among the respondents from the group of 5to 9 years of professional employment

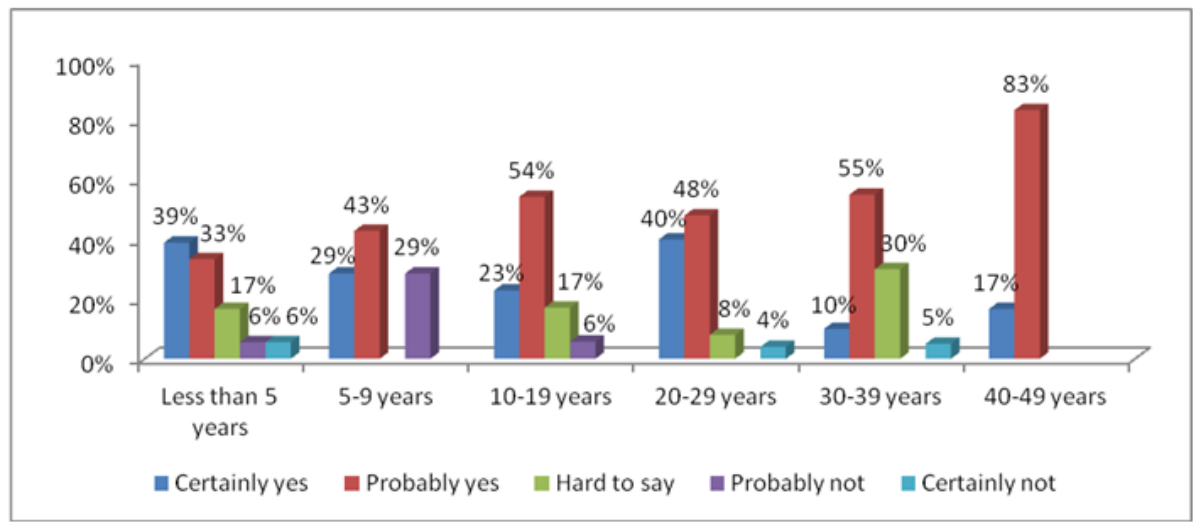

Figure 3. Answers to the question: "Do you feel that you have sufficient knowledge and skills for the current position?" according to the years of professional library experience (\% of the group) 
Although more than three-quarters of the respondents (77\%) feel that they have sufficient knowledge and skills for their current job, they would be still willing to learn something if this would result in increasing their salary (90\%).

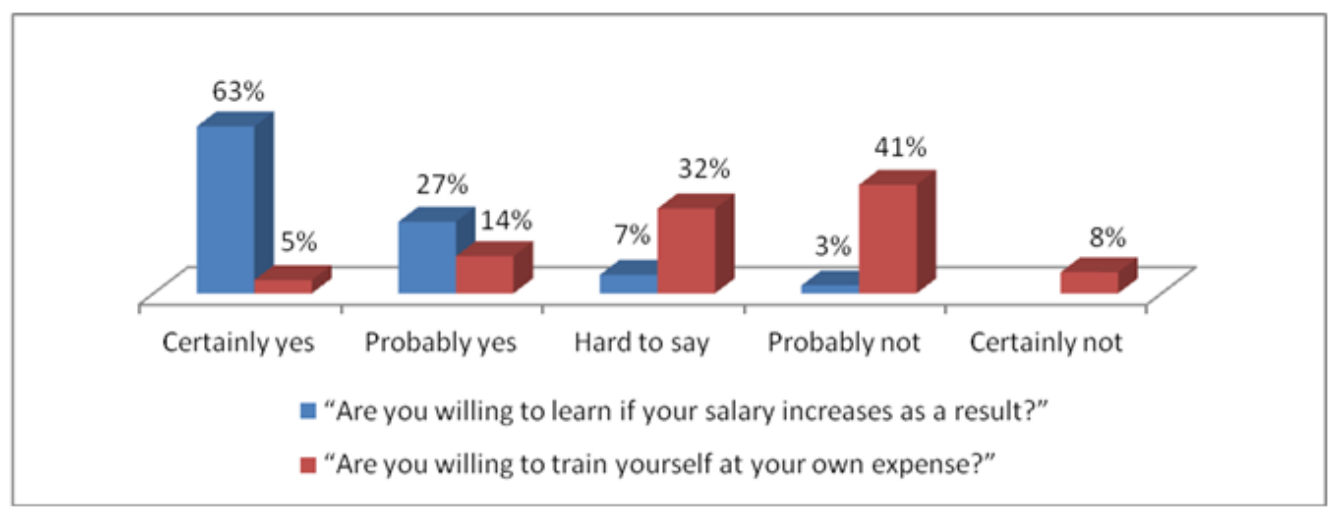

Figure 4. The impact of income and increasing salary to the willingness to learn

Taking into account that the vast majority of employees of the Estonian university libraries receive a monthly salary of less than $500 €$, it is understandable why $49 \%$ of those surveyed are not willing to educate themselves at their own expense.

Looking at respondents' willingness to study in sections of lenght of service in librarianship, almost every group is willing to learn, if it would result in increasing salary. Figure 5 shows that the ambition to learn raises up to the highest level among respondents with working experience of 5 to 9 years - 100\% of them wish to learn in the hope of better salary. This group also included the most of the sceptic ones about their sufficient knowledge and skills for their current position (see Figure 3). Only groups of 10 to 19 years, 20 to 29 years and 30 to 39 years of service contain small percentage of those, who are not enthusiastic about improving themselves for a potential rise in a salary in the future (respectively 3\%, 4\% and 5\%).

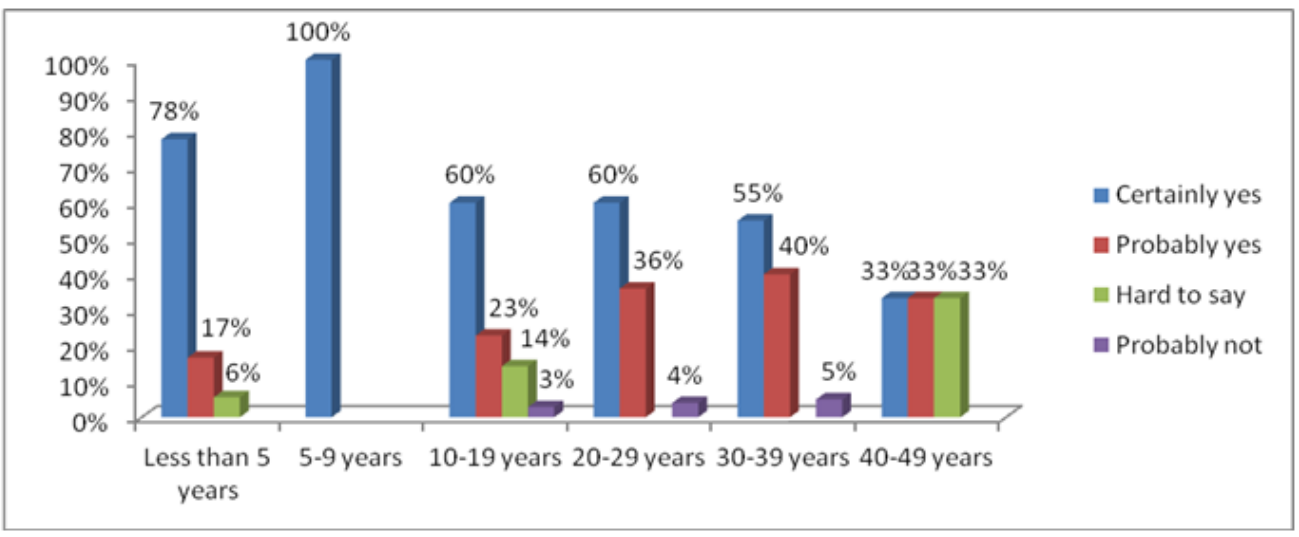

Figure 5. The respondents' willingness to learn if the salary increases as a result according to the years of professional library experience (\% of the group)

Although librarians generally are self-motivated in their professional development, organizational support is a key factor in creating a culture to encourage participation in learning and development activities.

An organization-based support for librarians' professional training and development is also essential in Estonia and it is certainly one aspect that requires in-depth investigation in the future. Also, clause 28 (2) 5) of the Estonian Employment Contracts Act (RT I 2009, 5, 35) gives an opportunity to cover part of the costs by stating that it is for the purposes of development of the professional knowledge and skills of an employee, to provide the employee with training based on the interests of the employer's enterprise. Clause 15 (2) 5) of the Estonian Employment Contracts Act, in turn, provides an employee with the following liability: to participate in training for improvement of vocational knowledge and skills. The above provisions are intended, among other things, to contribute to the awareness of the mutual training obligations and the valuation of the principle of lifelong learning. Since 2011, the employer can cover the costs of formal education acquired within the adult education system of an employee under certain conditions. Investing in the formal education acquired within the adult education system (e.g. master's studies or doctoral studies) that is related to an employee's job duties is justified if an employer has the right to expect the employee's contribution to the organization later on. How many libraries have used this opportunity to cover the employer's education costs is unfortunately unknown.

A total of 54 people responded to the following open question: "What kind of knowledge/skills do you miss the most in your current position?" The respondents mostly encountered difficulties with foreign languages. The answers to the open question in Table 1 show that 25 people feel the need for learning and improving language skills; mostly in English, Finnish and Russian; with Chinese and Japanese also mentioned. Secondly, lack of IT-related knowledge was mentioned (14 respondents). This includes both general computer skills and the need 
for specific technical knowledge. By M. Nofsinger (1999), technological skills are necessary for librarians. The information environment in libraries include an integrated library system to manage the OPAC, circulation, acquisitions, and cataloguing functions of the library; electronic information services; CD-ROMs; public access computers providing access to the Internet and to office software suites; local area networks (Wifi); imaging systems; and devices for visually handicapped users. Librarians should be able to use all these systems well enough to show the library users how to operate them.

Table 1. Formal activities preferred by the respondents

\begin{tabular}{|c|c|}
\hline Training form & \% of respondents \\
\hline In-service training & $33 \%$ \\
\hline In-service training, Training trip* & $35 \%$ \\
\hline Formal studies, Vocational courses, In-service training, Training trip & $9 \%$ \\
\hline Training trip & $9 \%$ \\
\hline Formal studies, In-service training, Training trip & $4 \%$ \\
\hline Formal studies, Vocational courses, In-service training & $2 \%$ \\
\hline Formal studies, Training trip & $2 \%$ \\
\hline $\begin{array}{l}\text { Vocational courses } \\
\end{array}$ & $1 \%$ \\
\hline Vocational courses, In-service training, Training trip & $1 \%$ \\
\hline Formal studies, Vocational courses, Training trip & $1 \%$ \\
\hline Formal studies, Vocational courses, In-service training, Training trip & $1 \%$ \\
\hline Did not respond & $2 \%$ \\
\hline Total & $100 \%$ \\
\hline
\end{tabular}

*For example, going to a foreign library to examine one's field in depth

Yet there appears to be a lack of managerial knowledge, conflict management skills (in this regard, particularly for readers), knowledge of history, binding and legislation.

What forms of training would staff of Estonian university libraries be willing to undergo? Answer choices were given as following: formal studies, vocational studies, in-service training and training trip (for example, going to a foreign library to examine one's field in depth). It was possible to select multiple answers and that option was used. Therefore, the most popular individual choices turned out to be in-service training, which was preferred by $33 \%$ of the respondents as a potential training form, and training trip, which was preferred by $9 \%$ of the respondents. Vocational training as a single option was preferred only by $1 \%$ of the respondents. In contrast, among those who selected several alternatives, the most popular combination was in-service training and training trip (35\%), and the combination of formal studies, vocational studies, in-service training and training trip or a combination of all the options - 9\%. The remaining combinations were less preferred.

The other forms of mentioned trainings included elearning, training/gaining experience from other Estonian libraries, a variety of foreign language courses (four times), and computer training. It was also mentioned that the salary is too low to attend trainings at one's own expense.
One of the most important components of a career are competence and good education, which requires continual acquisition and development of knowledge, skills and experience, also participation in specialty societies, professional conferences, and seminars. If the everyday work does not allow employees to implement their skills enough, they have the opportunity to seek challenges elsewhere. For instance, they can write presentations, take on a specialized topic in various conferences, seminars, and forums; in other words, they can be active outside of working hours. Although librarians often attend conferences primarily for professional rejuvenation and social networking, conferences are also perceived as valuable for learning purposes. If an employee is actively involved in professional activities outside of working hours, it is also beneficial for an employer (Türk, 2005, pp. 362-364). After all, all public university libraries in Estonia are simultaneously research libraries, which are required, in addition to other annual reports, to submit a research report each year.

As we can see from Figure 6, there are a number of employees in university libraries who would be willing to participate in professional conferences and seminars with the goal of self-improvement - as much as $84 \%$. But only $32 \%$ are ready to deliver a presentation, $20 \%$ are hesitant and, unfortunately, $48 \%$ of respondents do not want to perform at all.

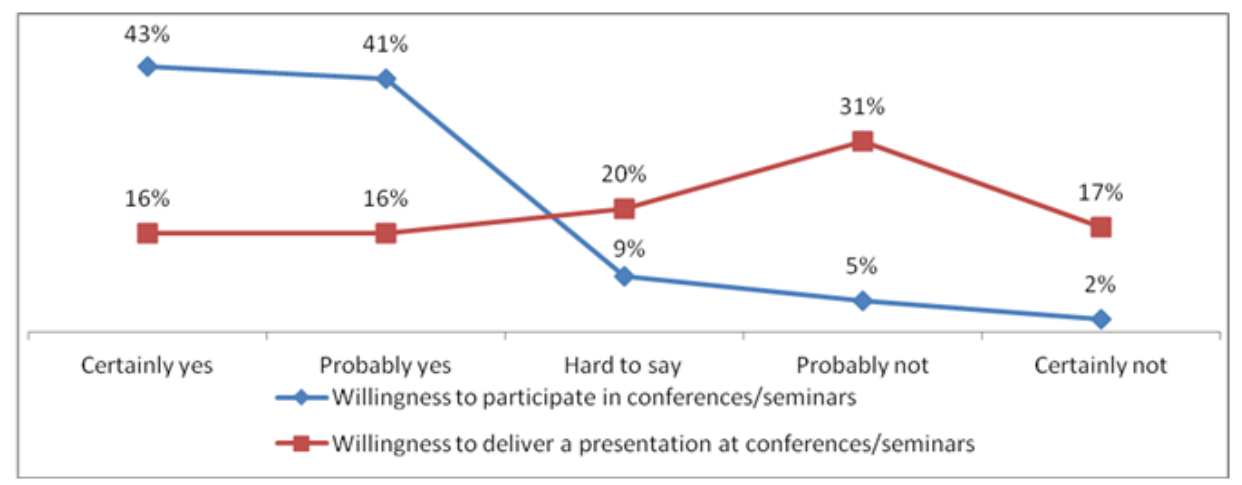

Figure 6. Librarians willingness to participate and perform in professional conferences

It is clear that the idea of public speaking in the presence of a large audience can be daunting, if it has not been done before. However, if an employee is interested in any professional topics, it can be assumed that the 
subject may be interesting to other librarians, and moreover, to the general public.

Figure 7 shows that the information about trainings and conferences/seminars has been sufficiently available: none of the participants in the survey did respond to these questions as "No, definitely not”.

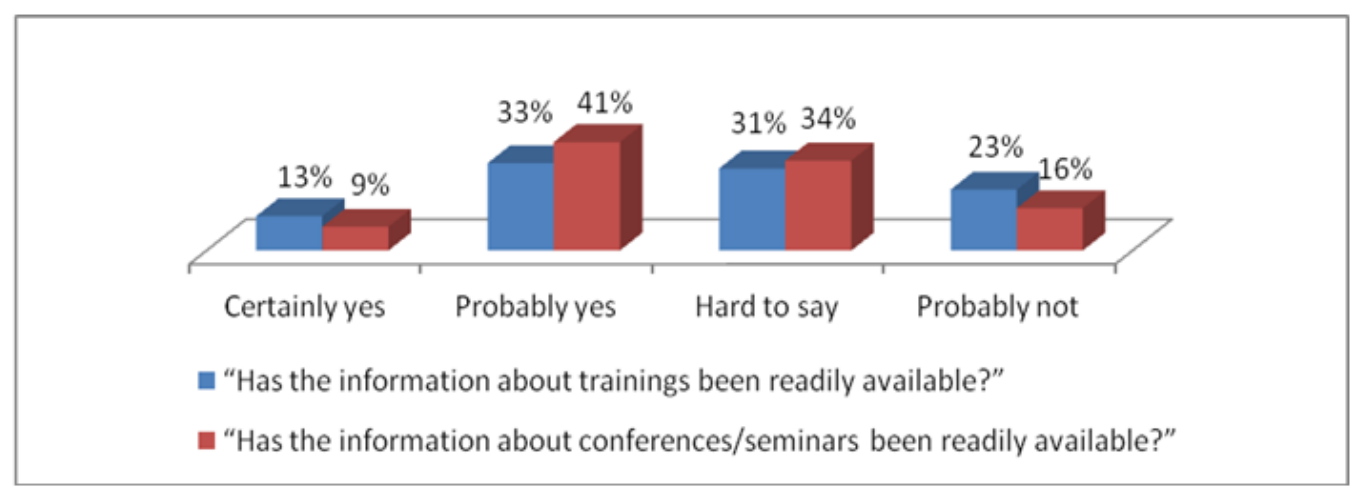

Figure 7. Avalability of the information about trainings and conferences/seminars

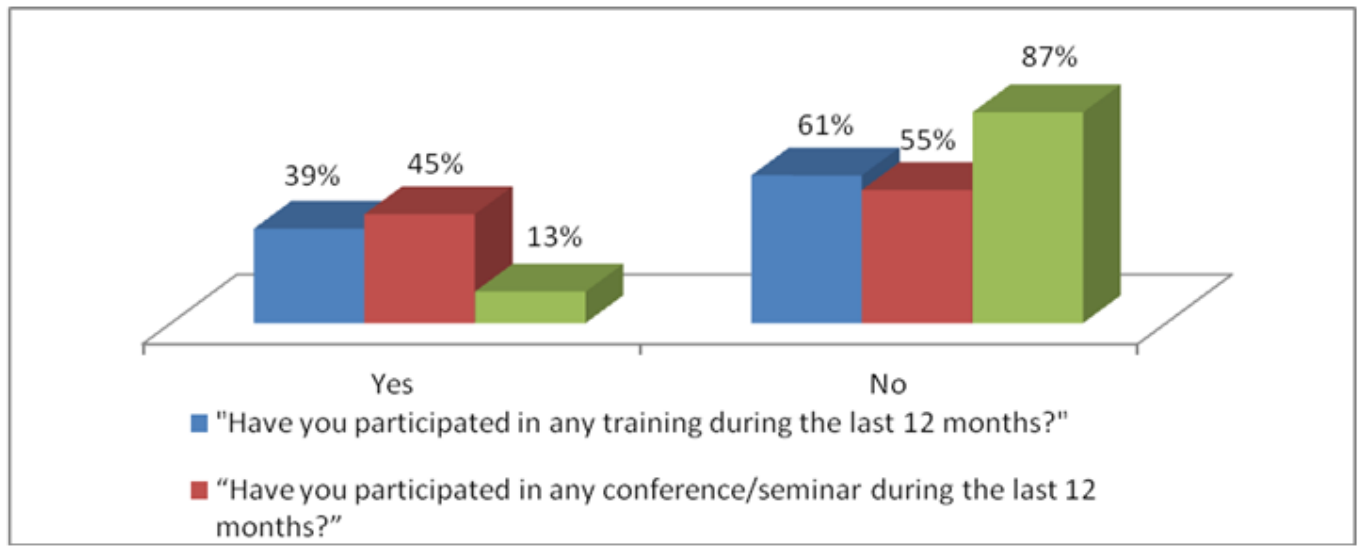

Figure 8. Librarians actual participation in trainings and seminars

Nevertheless, it is still surprising that $61 \%$ of the respondents have not participated in any training during the last 12 months (see Figure 8). Perhaps the university library personnel are not informed enough about the opportunities to take training trips, for example, to get acquainted with their professional field in some other country's library, offered by the Archimedes Foundation via the Erasmus-program meant for university staff. Erasmus is a higher education sub-programme under the European Lifelong Learning Programme. The nonacademic staff of universities may participate in trainings as well as in conferences under the Erasmus Programme. Time spent in training can last for 1 to 6 weeks. The programme lasts until the end of 2015.
By Auster \& Chan (2004, pp. 57-58) “Librarians nearing retirement may be reluctant to invest time and money in professional development they will hardly use, and libraries may be reluctant to invest in training librarians who will soon retire”. Fortunately, it is not the case in Estonian university libraries. Librarians with professional library experience of 40 to 49 years and 30 to 39 years are even more active participating trainings than their younger colleagues with library experience of 20 to 29 years (see Figure 9). As librarians with professional employment of 5 to 9 years willingness to learn was up to $100 \%$, it is seen that they are not only willing to participate in courses, but they also do that $-57 \%$ out of this group participated in some training during the last 12 months.

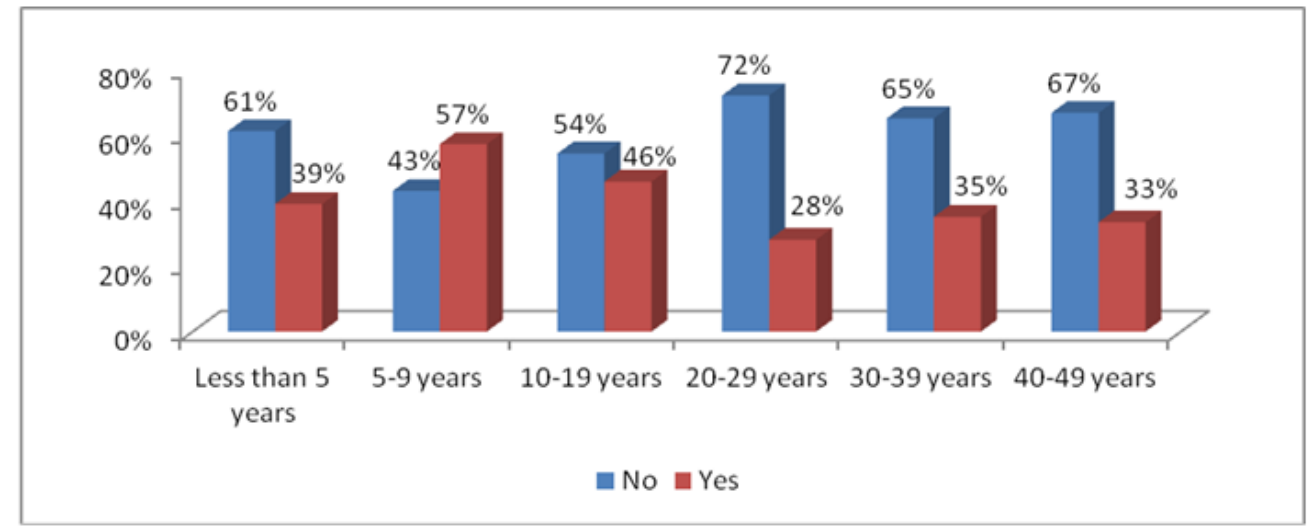

Figure 9. Distribution of the survey respondents participating in training according to the years of professional library experience (\% of the group) 
A total of $55 \%$ of the respondents have not participated in any conference/seminar during the last 12 months (see Figure 8). However, the latter is understandable since the attendance at conferences is usually supported by various funds in case the attendee is ready to make a presentation there. As only $13 \%$ speak at a conference, it will not yield a very high percentage of conference participants.

\section{Conclusions}

Although librarians generally are motivated in their professional development, and some of them are even willing to do it at their own expense, the bigger motivator is hope for increasing salary. Most of the respondents are willing to participate in an in-service training; also training trips are quite acceptable for many. Nearly a quarter of respondents are ready for formal studies. Most people are interested in learning languages.

It is very important for academic librarians to keep abreast of the profession as it changes so rapidly. One of the best ways to do this is by attending professional workshops, lectures, seminars, and also by participating in specialty societies, professional conferences, and seminars. Most of the respondents are willing to participate in conferences and seminars with a purpose of selfimprovement, and most of them have done it within the last 12 months. Another important professional development activity is giving presentations to colleagues and community groups. It is very useful for librarians to share their experiences about the topic that is interesting for presenter or about the project he/she has completed at work. Librarians should not underestimate themselves; there are an incredible variety of conferences, meetings, symposiums, etc. going on all the time. A total of $35 \%$ of respondents would be willing to give presentations, unfortunately only $18 \%$ of them have performed one within the last 12 months.

Although the administrative support may include a variety of approaches, like take care that there is no lack of knowledge about the learning and development activities, the main issue for Estonian university librarians is the salary at the moment. On the basis of the reality that the major part of respondents receive monthly income less than $500 €$, today the first and most critical issue for libraries is to increase employees' salary and by that improve their economic status. The authors of the survey are of the opinion that employers should support the employees' training and participation in seminars and conferences and provide greater encouragement for active participation, in other words performing and sharing experiences. The library's financial and/or time support could influence the self-development activities of an employee, the participation in professional seminars, conferences, workshops, and meetings. Additional benefits include the fact that the employees' participation in continuing education will contribute to the advancement of the profession: for example, librarians will get to know better colleagues around the country and abroad. This in turn makes the employees' a better librarians and everyone benefits including students, faculty members, administrators, and colleagues.

\section{References}

[1] Anyangwe, E. (2012). "Professional Development Advice for Academic Librarians", Guardian Professional, Thursday 22 March. Web http://www.theguardian.com/higher-educationnetwork/blog/2012/mar/22/professional-development-foracademic-librarians17March 2014.

[2] Armstrong, M. (2012). Armstrong's Handbook of Human Resource Management Practice. London: Kogan Page.

[3] Auster, E., Chan, D. C. (2003). "Reference Librarians and Keeping Up-to-Date: A Question of Priorities”, Reference \& User Services Quarterly, Vol. 44, No. 1, pp. 57-66.

[4] Chan, D. C., Auster, E. (2004). "Factors contributing to the professional development of reference librarians", Library \& Information Science Research, Vol. 25, No. 3, pp. 265-286.

[5] Brooks, I. (2008). Organisatsioonikäitumine: Üksikisik, rühm ja organisatsioon [Organisational Behaviour: Individuals, Groups and Organisation]. Tallinn: Tänapäev.

[6] Buckley, R., Capley, J. (2007). The Theory and Practice of Training. Cornwall: MPG Books.

[7] Fisher, W., Matarazzo, J. M. (1993). "Professional Development for Special Librarians: Formal Education and Continuing Education for Excellence”, Library Trends, Vol. 42, No. 2, pp. 290-303.

[8] Flately, R. K., Weber, M. A (2004). "Perspectives on Professional development opportunities for new academic librarians", The Journal of Academic Librarianship, Vol. 30, No. 6, pp. 488-492.

[9] Havener, W. M., Stolt, W. A. (1994). "The Professional Development Activities of Academic Librarians: Does Institutional Support Make a Difference?”, College \& Research Libraries, Vol. 55, No. 1, pp. 25-36.

[10] Hegg, J. L. (1985). "Continuing Education: A Profile of the Academic Librarian Participant”, Journal of Library Administration, Vol. 6, No. 1, pp. 45-63.

[11] Hider, P. (2006). "A Survey of Continuing Professional Development Activities and Attitudes Amongst Catalogers", Cataloging \& Classification Quarterly Vol. 42, No. 2, pp. 35-58.

[12] Leysen, J. M., Boydston, J. M. K. (2009). “Job Satisfaction among Academic Cataloger Librarians”, College \& Research Libraries, Vol. 70, No. 3, pp. 273-297.

[13] Livingstone, D.W. (1999). "Exploring the Icebergs of Adult Learning: Findings of the First Canadian Survey of Informal Learning Practices", Canadian Journal for the Study of Adult Education, Vol. 13, No. 2, pp. 49-72.

[14] Long, C. E., Applegate, R. (2008). „Bridging the Gap in Digital Library Continuing Education: How Librarians Who Were Not "Born Digital" Are Keeping Up", Library Leadership and Management, Vol. 22, No. 4, pp. 172-182.

[15] Neal, J. G. (1980). "Continuing Education: Attitudes and Experiences of the Academic Librarian", College \& Research Libraries, Vol. 41, No. 2, pp. 128-133.

[16] Nofsinger, M. M. (1999). "Training and Retraining Reference Professionals. Core Competencies for the 21st Century", The Reference Librarian, Vol. 30, No. 64, pp. 9-19.

[17] Pan, J., Hovde, K. (2010). "Professional Development for Academic Librarians: Needs, Resources, and Administrative Support", Chinese Librarianship: an International Electronic Journal, No. 29. Web http://www.iclc.us/cliej/cl29PH.pdf. 20 October 2013.

[18] Reynolds, J., Mason, R. (2002). How do People Learn? Research Report for CIPD, Prepared by the University of Cambridge Programme for Industry. Web http://www.thelearningbusiness.com/Communities/BTCTCS/PDF Files/HowDoPeopleLearnExtractsforSeminars1.pdf 28 October 2013.

[19] Shelley, A., Nedria, S. (1990). "Administrative Support for Research: A Survey of Library Faculty”, Library Administration and Management Vol. 4, pp. 208-212.

[20] Senyah, Y. (2003). Motivation and Productivity in Academic Libraries: "A Case Study of the Kwame Nkrumah University of Science and Technology Library, Kumasi”, Journal of Science and Technology Vol. 23, No. 2, pp. 80-89.

[21] Smith, D., Burgin, R. (1991). "The Motivations of Professional and Paraprofessional Librarians for Participating in Continuing Education Programs”, Library \& Information Science Research, Vol. 13, No. 4, pp. 405-429. 
[22] Steptoe-Warren, G. (2013). Occupational Psychology. Harlow: Pearson Education Limited.

[23] Stone, E. W. (1970). "Librarians and Continuing Education", Journal of Education for Librarianship, No. 2, pp. 64-71.

[24] Tella, A., Ayeni, C. O., Popoola, S. O. (2007). "Work Motivation, Job Satisfaction, and Organisational Commitment of Library Personnel in Academic and Research Libraries in Oyo State, Nigeria”, Library Philosophy and Practice, Vol. 9, No. 2. Web http://www.webpages.uidaho.edu/ mbolin/tella2.pdf. November 2012.

[25] Türk, K. (2005). Inimressursi juhtimine. [Human Resource Management]. Tartu: Tartu Ülikooli Kirjastus.

[26] Varlejs, J. (1999). "On Their Own: Librarians' Self-Directed, Work-Related Learning”. The Library Quarterly, Vol. 69, No. 2, pp. 173-201.

[27] Woodsworth, A. (1998). "Learning for a Lifetime”, Library Journal, No. 123, p. 62. 